\title{
EVALUATION OF THE GROWTH AND CARCASS CHARACTERISTICS OF THE JAPANESE QUAIL (Coturnix conturnix japonica) IN NIGERIA
}

\author{
AYORINDE, K.L. \\ Department of Animal Production, University of Ilorin, Ilonin, Kwara State. Nigeria. \\ Reccived 22 April 1993; accepted 28 November 1993
}

\section{ABSTRACT}

Two experiments were designed to study the growth and carcass characteristics and the effects of system of management on the Japanese quail. In the first experiment, 138 birds raised to 8 weeks of age were used to study the growth and carcass characteristics of quails. Day old weight averaged $8.67 \pm 0.75 \mathrm{~g}$ while body weights at 4 and 8 weeks of age were $130.38 \pm 21.81 \mathrm{~g}$ and $175.08 \pm 21.23 \mathrm{~g}$ respectively. Feed conversion rate to 8 weeks was 6.42 with each bird consuming $1067.68 \mathrm{~g}$ feed. No significant sex differences $(P>0.05)$ were observed in the average yield of parts although the males had slightly higher dressed and eviscerated weights and percent wing, back and neck than females. Dressed weight was $93.55 \%$ on the average while eviscerated weight was $68.61 \%$. the carcass contained $74.20 \%$ moisture, $69.63 \% \mathrm{CP}$ and $26.5 \%$ fat. In the second experiment, 120 birds were used to test the effect of management system (lloor vs. cage) on growth and carcass characteristic of the quail. Although floor rearing had a slight advantage over cage rearing in terms of weight gain, feed conversion ratio and carcass yield, the differences were not significant $(P>0.05)$.

Key Words: Quail, Growth, Carcass yield, carcass composition, Acceptability, management system.

\section{INTRODUCTION}

Animal protein has continued to decrease in Nigeria as a result of the high cost of the products arising principally from the continually increasing cost of production. One way of increasing protein supply is to diversify poultry production as well as increase the production of other livestock species with short generation intervals. One of such animal is the quail.
Quail production is not yet popular in Nigeria unlike in countrics like Japan, India, Philippines, etc. where its production has been heavily commercialised. This is probably bccause the advantages of quail compared with the domestic fowl, the main source of poultry meat and egg (Wilson of al, 1959, 1961; Schwart\% and Allen, 1981; El-Ibiary et al., 1966) have not been realised in Nigeria.

There is presently no reported study of the performance and characteristics of quails in Nigeria. This study was designed to evaluate the growth ratc, carcass, effect of management system and relationships between body weight and yicld of cul up parts in Japanese quail.

\section{MATERIALS AND METHODS}

Two experiments were designed to study the growth and carcass characteristics of the Japanese quail.

\section{EXPERIMENT I.}

A total of 138 day-old Japanese quails hatched from eggs obtained from a private farm in Kwara Stae, Nigeria were divided into six replicates of 23 birds each and reared on the deep litter 108 weeks of age at the rate of 20 birds per $\mathrm{m}^{2}$. Weckly measurements of body weight and feed intake were taken from day old to 8 wecks. At eight weeks of age, twenty birds (ten of each sex) were randomly picked, kept off feed overnight and slaughtered by severing the jugular veins. After scalding in warm water for about a minute and manually plucking the feathers, each bird was cut into parts: heads, back and neck, breast, wing, thigh and drumstick, shank, liver, heart and gizzard. Each cut up part was then weighed.

Triplicate samples of the manually deboned meat of five carcasses of each sex were analysed for moisture, crude protein and ether extract in accordance with the methods of AOAC (1985). 
Twenty panelists were trained for organoleptic assessment (colour, flavour, tenderness, juiciness and overall acceptability) of the prepared samples Irom each sex using the Nine-point Hedonic Scale (Cover et al. 1962). Ten of the panelists were chosen for the sensory evaluation. Broiling of the meat from each sex was done in an open gas oven at a lemperature of $72^{\prime \prime} \mathrm{C}$. The hroiled meat of each sex was cut into biteable sample sizes and served on a tray to each of the ten screcned panelists who were each given a taste panel score form. The panelists were told to rate each of the orgatioleptic traits independently of each other. Cool water was served to the judges to rinse their mouth after scoring for the first simple.

\section{EXPERIMENT 2.}

One hundred and lwenty daty old bajanese quail hatched from a foundation stock kept in the Department's Animal Pavilion were used for the research. The hirds were divided into four replicates to investigate the effect of rearing system on the growth performance and carcass yield of Japanese quait. Two replicates were reared to 4 weeks of age in baltery cages meastiring $0.5 \% \mathrm{~m} \times 0.30 \mathrm{~m}\left(0.013 .3 \mathrm{~m}^{2}\right.$ bir $\left.\mathrm{d}^{-1}\right)$ while the other (wo groups were raared on the deep lifter permiting a floor space of $0.0339 \mathrm{~m}^{2}$ per bird.

At 4 weeks of age, the chicks raised in the batlery cages were mixed together and randomly divided into lour new groups. Two groups (replicates) were raised in battery cages and the other two on the deep litter to s weeks of age. Similarly the lwo groups on the floor were divided into four new groups and two groups each assigned to decp litter tion or battery cage. Thus four different rearing systems: Cage - Cage (C-C), Cage-lloor (C- F), Floor-Cage (F-C) and floor-floor (F-F) were used for raising the birds to 8 wecks of age. Body weights, feed inlake and mortality were recorded weckly for each group.

At 8 weeks of age, five hirds from each replicate (10 per group) picked randomly were slaughtered, dressed and cut into parts as in experiment 1.
The birds in both experiments were fed diets containing $28.4 \% \mathrm{CP}$ and $3350 \mathrm{kcal} / \mathrm{kg}$. feed and $21.7 \% \mathrm{CP}$ and $3044 \mathrm{kcal} / \mathrm{kg}$. feed between $0-4$ and $4-8$ weeks of age respectively.

\section{STATISTICAL ANALYSES.}

Body weight and carcass yield data were subjected to one way analysis of variance using the completely Randomised Design while difference in feed intake, feed conversion, sensory evaluation and proximate composition were distinguished using the t-test (Steel and Torrie, 1980). Correlations between live body weight and cut up parts were also determined.

\section{RESULTS AND DISCUSSION}

\section{EXPERIMENT 1}

The mean weekly boc: weights, body weight ranges, feed intake, and feed conversion ratio as well as number of birds measured weckly are presented in Table 1 . The birds weighed on the average $8.67 \pm 0.75 \mathrm{~g}$ at day old and $175.08 \pm$ $21.23 \mathrm{~g}$ at 8 weeks of age. The most rapid stage of growth was during the first four weeks of age $(4.35 \mathrm{~g} / \mathrm{hird} / \mathrm{day})$ but in consequence of onset of puberty the growth slowed down between 4 and 6 weeks of age (0.63g/bird/day). Mean daily weight gain between 6 and 8 weeks of age was $2.56 \mathrm{~g}$. The overall daily gain to 8 weeks was $2.97 \mathrm{~g} /$ hird. The body weights oblained in this study compare favourable with values reported by workers in temperate countries (Bacon and Nestor, 1983, Lepore and Marks, 1971, Jones et al. 1979, Sadjadi and Becker, 1980).

The tolal cumulative feed intake to 8 weeks of age was $1067.68 \mathrm{gg}$ per hird. Compared wilh $1757 \mathrm{~g}$ in the unimproved guinea fowl (Ayorinde of al, 1988), $1872 \mathrm{~g}$ in the improved guinca fowl (Verma of al. 190)(1) to 10 weeks of age and $3277 \mathrm{~g} \mathrm{to} 5$ wecks of age in the domestic fowl broilers (Adeleyc and ()dunsi (19)(0)

The highest feed intake was around the onset of puberty when the birds had to combine body weight gain with physiological development for egg and semen production. The fairly high feed intake despite the obviously low body weight and hence the resultant poorer feed efficiency of the quail is probably due to a higher metabolic 
rate. This no doubt will place the quail at a disadvantage in terms of cost of production.

The feed conversion ratio up 104 wecks of age was comparable to what obtains in the guinea fowl (Ayorinde, Oluyemi and Ayeni, 1988) and in the domestic fowl broilers (Oluyemi and Roberts; 1979). However during the 5th and 6th wecks of age, feed conversion ratio was particularly high as little body weight was gained and the birds had to divert much of the feed to physiological changes for initiating onset of puberty. The cumulative feed conversion ratio to 8 weeks of age was 6.42 . This compares favourably with the 5.28 reported by Ayorinde $c t$ al. (1988) for the unimproved guinea fowl but is much poorer than values reported for broilers, (Nwachukwu and Ibe 1990, Adcleye and Odunsi, 1990). Compared with the guinea fowl and domestic fowl broilers the quail has poorer feed efficiency. The body weight of the quail at a similar age is about $36.8 \%$ of that of the local guinea fowl (Ayorinde et al, 1988) and only $9.5 \%$ of that of the broiler (Adeleye and Odunsi, 1990). Yet at this age, feed intake of the quail was about $61 \%$ of that of the guinea fowl and $32.6 \%$ of that of the domestic fowl broiler

Mortality was generally low during the brooding period (0-4 weeks) being only $2.17 \%$ and was only $3.62 \%$ to 8 weeks of age. This indicates that the quail is a very rustic bird and perhaps less disease-prone than other poultry birds.

The age at which egg production commenced in the birds used for this study was similar to the 35 days of age reported by Sefton and Siegel (1974). Since the birds came into lay in the 6th week of age, they can be considered very profilic or early maturing with a high production rate suitable for meeting the meat and egg needs of most homes.

Table 2 shows the mean live weight and cut up parts as percent of liveweight in the two sexes at 8 weeks of age. Though the females had slightly higher body weights than the males, no significant $(P>0.05)$. differences were observed in the vaxious parts between the two sexes. Except for the legs (thing + drumstick + shank) and the giblets, the other parts formed a higher percentage of the liveweight in the males.

As observed by Wilson et al (1961), the larger body weight of the females was probably due to heavier gonads, intestines, gizzard and liver, hence the higher dressing and eviscerated percentages obtained for females in this study. The dressing and eviscerated percentages obtained in this study werc higher than those reported for the broiler chicken (Singh and Essary, 1974), guinea fowl (Ayorinde, 1989) and the bush fowl (Akande and Oluyemi, 1984).

There were no significant $(\mathbf{P}>0.05)$ differences in the proximate composition of the two sexes (Table 3) although the males had slightly higher dry matter and crude protein but lower moisture and fat than the females.

The slightly higher fat $(+1.1 \%)$ observed in the females was probably as a result of changes in the physiological status of the birds. The moisture and dry matter content of quail meat compare favourably with those of the domestic fowl broiler (Singh and Essary, 1974) but contained higher moisture than those of the guinea fowl (Ayorinde, 1989), bush fowl (Akande and Oluyemi, 1984, Famuyiwa, 1988), doves, pigeons, ducks and local chicken (Famuyiwa, 1988) perhaps as a result of younger age. The fat content of the meat also compares favourably with that present in bush fowl, doves, ducks, pigeon (Akande and Oluyemi, 1984, Famuyiwa, 1988) and guinea fowl (Ayorinde, 1989). On dry matter basis, the protein content of the meat of Japanese quail compare well with those of other domestic and wild birds (Akande and Oluyemi, 1984; Ayeni et al, 1983; Ayorinde, 1989).

The results of the sensory evaluation of the meat samples are shown in Table 4. There were no significant differences $(P>0.05)$ in color, juiciness and overall acceptability of the meat samples of the two sexes. The colours of the meat samples according to the panelists were intermediately deep for males (Score $=5.2$ ) and slightly pale for females $($ Score $=6.00)$. the juiciness of the meat samples from the two sexes 
were judged to be intermediate in wetness (5.5-5.6) and the flavour was liked moderately by the panelists. According to the penalists, meat of male quails was only slightly tender while that of the female was moderately tender.

The organoleptic assessment of the Japanese quail meat shows that it is readily acceptable by consumers and hence should have no problem of acceptance in Nigeria if enough could be produced. The overall scores indicated that the meat of Japanese quail is intermediate between deep and pale, liked moderately, moderately tender and slightly juicy.

Table 5 shows the correlation between live weight and the cut up parts at 8 weeks of age. All the cut up parts except the wings were positively and significantly $(\mathrm{P}<0.05)$ correlated to live weight. Except for wing weight and dressed weight, breast weight and back + neck, the other cut up parts also showed positive and significant $(P)$ inter-corrclation. The correlation values indicated that the cut-up parts and carcass yield could be reliably predicted from the liveweight.

\section{EXPERIMENT II.}

The mean weekly body weight, feed intake, and feed conversion of the four groups between 0 and 8 weeks of age are shown in Table 6 . The growing system had no significant ( $\mathrm{P}>0.05$ effect on the above parameters although floor rearing proved better than cage rearing. Weight gain per day between 0 and 4 weeks of age was $5.4 \mathrm{gg}$ in the cage and $5.75 \mathrm{~g}$ on the floor. Between 5 and 8 weeks of age, daily weight gain averaged $2.39 \mathrm{~g}$ in the cage and $2.74 \mathrm{~g}$ on the the floor. Over the 8 wecks period, daily weight gain was 3.94 and $4.16 \mathrm{~g}$ for the cage and floor respectively.

Cumulative feed intakes to 8 wecks of age were $1057.19,1082.13,1120.48$ and $1031.66 \mathrm{~g}$ for the $C, C, F-C, C$, $-F$ and $F-F$ groups respectively. Feed intake to 4 weeks of age were $412.74 \mathrm{~g}$ for the cage and $411.15 \mathrm{~g}$ for the floor. The birds consumed 649.39 and $645.39 \mathrm{~g}$ on the average between 5 and 8 weeks of age when raised in the cage or on the floor. Thus the overall feed intake to 8 weeks of age was $1052.13 \mathrm{~g}$ for the cage and $1056.90 \mathrm{~g}$ for the floor.

Efficiency of feed utilization declined with age and was worst in week 6 but was slightly better for the floor reared group. The feed conversion ratio to 4 weeks of age was 2.69 for the cage and 2.56 for the floor. Feed convertion ratios of 9.68 and 8.77 were obtained between 4 and 8 weeks of age for the cage and floor reared groups respectively. The overall feed conversion ratio for the cage and floor were 4.83 and 4.51 respectively.

Mortality was generally low in the four management systems. Only 1 bird died from each of the groups during the 0-4 weeks brooding period and none during the 5.8 weeks rearing period.

The liveweight and carcass yield of birds from the four rearing systcms, as percentage of liveweight, are shown in Table 7. No significant differences were noted between the four groups although floor rearing had slightly better dressing and eviscerated percentages as well as higher cut up parts.

Though the result. indicated slightly better performance, weight gain, feed conversion and carcass yield on the floor than in cages, the ease of handling and high stocking density tend to favour cage rearing expecially in places where floor space could be a problem. The non-significant difference in the performance of birds raised under the two management systems was similar to that observed in pullets (Silva $e t$ al, 1979), broilers (Dexamir et al 1979), layers (Oluyemi et al 1975) and guinca fowl (Ayorinde and Ayeni, 1987). The eviscerated percentages obtained in this study were higher than the $77 \%$ reported by Jones et al. (1979) for floor reared Coturnix at 9 weeks of age and the $75.7 \%$ for 8 weeks old battery reared coturnix.

Evidence from the present study indicated that the quail has some characteristics that include fast growth, marketability at 6-8 weeks of age as indicated by request for the birds even when sold at $\$ 15.00$ each, smallness and easy handling, nonflightiness, less floor space 
requirement, high survival, early sexual maturity, high rate of egg production, short incubation period and short generation interval. It appears, however, that it may serve more as a variety meat rather than a cheaper source of poultry protein than both domestic fowl and guinea fowl considering its fairly high fecd intake and much smaller body size.

\section{REFERENCES}

ADELEYE, I.O.A. and ODUNSI, A.A. (1990.) Utilization of Rubber seed meal as protein supplement in broiler finisher rations. Nig.
J. Anim. Prod. 17:23-28.

AKANDE, M. and OLUYEMI, J.A. (1984) Carcass yield of the bush fowl (Francolinus bicoloratus.) Nig. J. Anim. Prod. 11 (2)
175- 177.

A.O.A.C. (1985.) Association of Official and Agricultural Chemists. Official method of Analysis. Washington. D.C.

AYENI, J.S.O.; TEWE, O.O. and AJAYI S.S. (1983.) Body measurements, egg characteristics and carcass composition of the guinea fowl: Trop. Agric. (Trinidad). 60
(3)! 224-227.

AYORINDE, K.L. (1989.) Carcass yield and chemical composition of four indigenous guinea fowl varieties at different ages. Bull. Anim. Hlth. Prod. Afr. 37: 361-366

AYORINDE, K.L. and AYENI, J.S.O. (1987.) Effect of management system on the fattening of indigenous pearl guinea fowl (N.M. galeata pallas) in Nigeria Trop.

AYORINDE, K.L. OLUYEMI, J.A. and AYENI, J.S.O. (1988.) Growth performance of four indigenous helmeted guinea fowl varieties (Numida meleagris galeata Pallas) in Nigeria. Bull. Anim. Hith. Prod. Afr. 36:
356-360.

BACON, W.L. and NESTOR, K,E. (1983.) Divergent selection for body weight and yolk precursor in Cotrunix Cotumix japonica. 4. Correlated responses in carcass composition and carcass yields of progeny during growth. Poult. Sci. 62:537-544.

COVER, S., HOSTERLAR, R.L. and RITHCHEY, S.J. (1962.) Tenderness of beef - IV Relationships of shear force and fiber extensibility to juiciness and six components of tenderness. J. Food Sci. 12:527-536.

DEXAMIR, A., VISAN, I., SPIRIDON, G., POPESA, A. and INCLUEX, E. (1979.) Comparison of rearing broilers on the floor and in battery cages. (Poult. Abs.) Pouit.
EL-IBIARY, H.M.,GODFREY, E.F. and SHAFFNER, C.S. (1966.) Growth and reproduction of Quails. Poult. Sci.

FAMUYIWA, M.A. (1988.) Carcass evaluation and Organoleptic assessment of quality attributes of wild birds. B.Sc. Thesis, Department of Animal Production,

JONES, J.E., HUCHES, B.C. and HALE, K.K (1979.) Coturnix quail Carcass yield. Poult. Sci. 58: 1647 - 1648 .

LEPORE, P.O. and MARKS, K.L. (1971.) Growth rate inheritance of Japanese Quail.
Poult. Sci. 50:11991 - 1193.

NWACHUKWU, E.N. and IBE, S.N. (1990.) Effects of quantitative feed restriction on broiler growth and economics of production. Nig. J. Anim. Prod. 17: 6-10.

OLUYEMI, J.A., YOMI, O. and ROBERTS, F.A. (1975.) The cage versus deep litter system for the management of layers in humid tropic. Poult. Sci. 54: 1982-1989.

OLUYEMI, J.A. and ROBERTS, F.A. (1979.) Poultry Production in warm wet climate. 1st. ed. Macmillan press Ltd. London and
Basingstoke.

SADJADI, $M$. and BECKER, W.A. (1980.) Heritability and Genetic Correlations of body weight and surgically removed abdominal fat in Coturnix Quail. Poult. Sci. 59: 1977 - 1984.

SCHWARTZ, R.W. and ALLEN, N.K. (1981.) Effect of ageing on protein requirements of mature female Japanese Quail for egg
production. Poult. Sci. 60: 342-348.

SEFTON, A.E and Sci. 60: 342-348.

Inheritance of SIEGEL, P.B. (1974.) Quail. Poult. Sci. 53:1597-1608 in Japanese

STEEL R

Principles and procedures of J.H. (1980.) Biometric Approach. 2nd of Statistics. A Book. Co. New York.

SINGH, S.P. and ESSARY, P.O. (1974.) Factors influencing dressing percentage and tissue composition of broilers. Poult. Sci. 53:2143-2147.

VERMA, S.V.S., HARPREET SINGH and SINGH, B.P. (1990.) Protein and energy requirements by guinea fowl keets. Proc. 13th Poult. Sci. Conf. and Symp. IJPS, Bombay 20-22 December, 1990. P.49.

WILSON, W.O., ABBÓT, U.K. anit ABPLANALP, H. (1959.) Development and physiological studies with a new pilot animal for poultry - Coturnix quail. Poult. Sci. 38:
1200 .

WILSON, W.O., ABBOT, U.K. and ABPLANALP' H. (1961.) Evaluation of Coturnix (Japanese Quail) as a pitos animal
for Poultry. Poult. Sci. 40:657. 
K. L. AYORINDE

Table 1 MEAN BODY WEIGHT (G) FEED CONSUMPTION (G/BIRD) AND FEED CONVERSION RATIO IN JAPANESE QUAIL \pm SE.

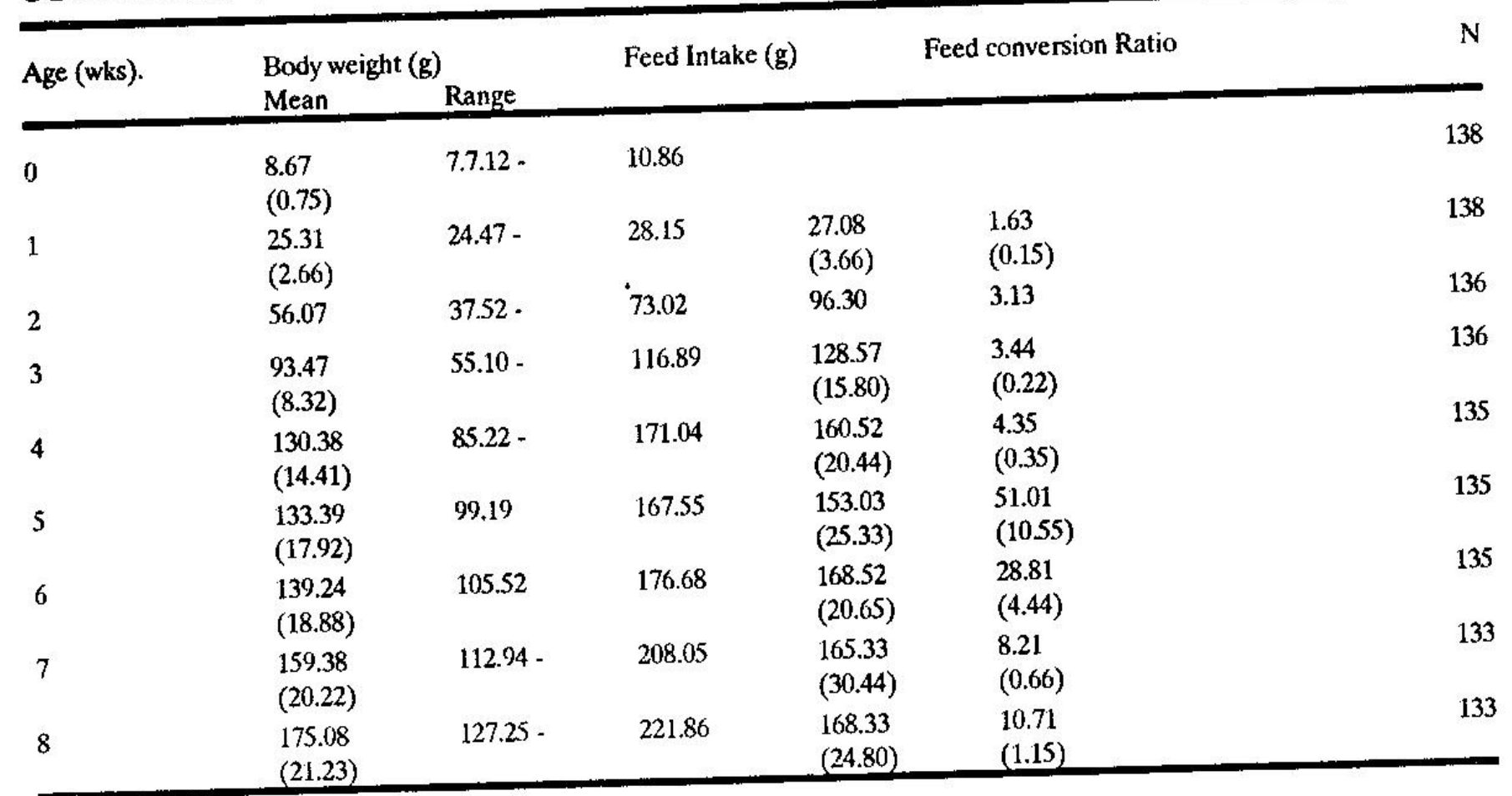

S.E. $=$ Standard Error (in parentheses)

Table 2 CARCASS YIELD (\%LIVEWEIGHT) OF MALE AND fEMALE JAPANESE QUAIL \pm SE.

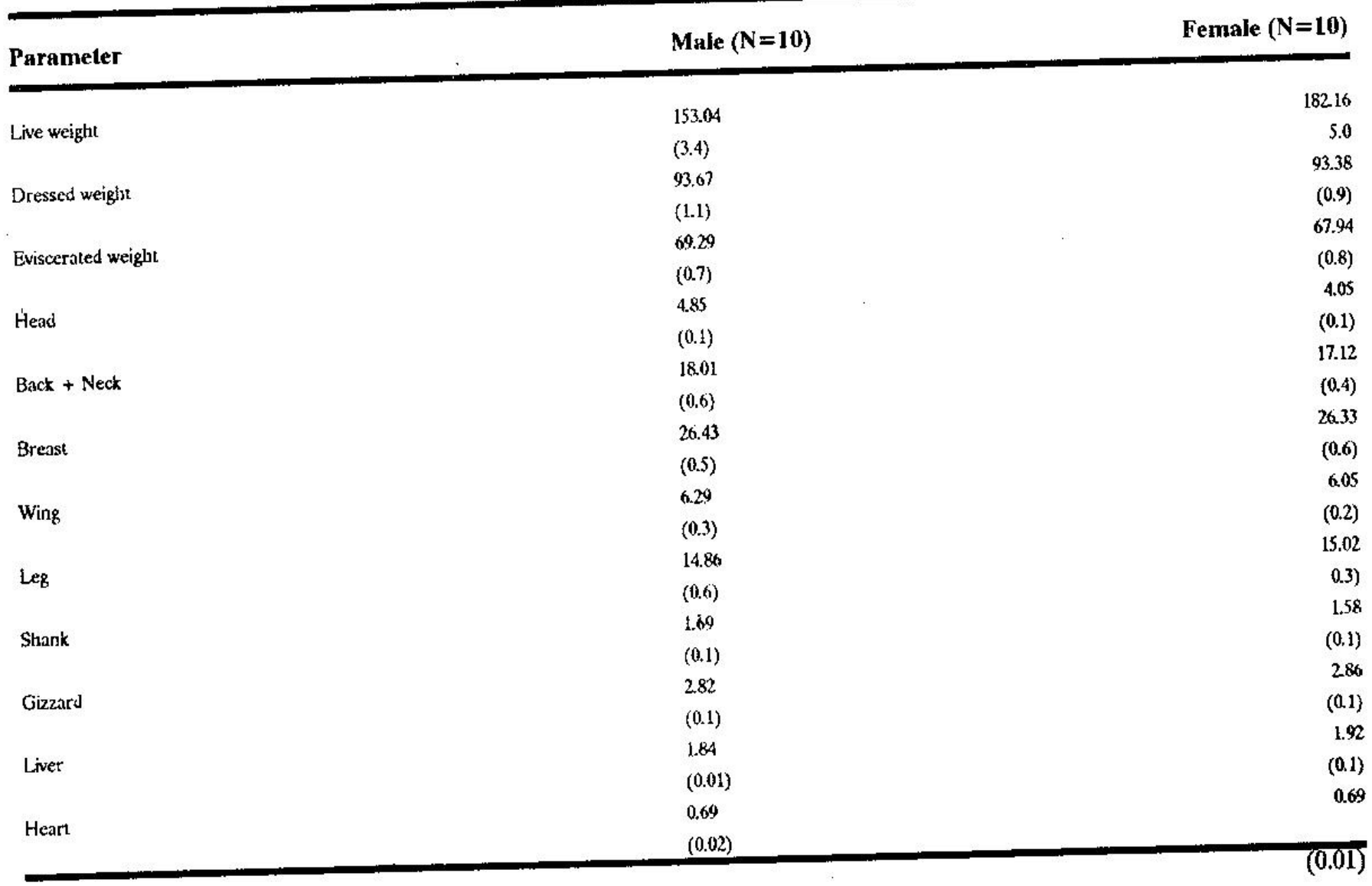

S.E = Standard Error (in Parentheses). 
Table 3 PROXIMATE COMPOSITION (\%) OF MEAT SAMPLES OF MALE AND FEMALE JAPANESE QUAIL \pm SE.

\begin{tabular}{lll}
\hline Parameter & Male $(\mathrm{N}=5)$ & Female $(\mathrm{N}=5)$ \\
\hline Moisture & 73.79 & 74.69 \\
Dry matter & $(0.8)$ & $(0.6)$ \\
Crude protein & 26.21 & 25.32 \\
Fat & $70.5)$ & $(0.8)$ \\
& $(0.3)$ & $(0.5)$ \\
& 25.85 & 27.05 \\
\hline
\end{tabular}

S.E. $=$ Standard Error (in parentheses)

Table 4 ORganOLEPTIC EVALUATION OF MEAT OF JAPANESE QUAIL (10 panelists) \pm
SE.

\begin{tabular}{lllr}
\hline Parameter & Male $(\mathrm{N}=5)$ & Female $(\mathrm{N}=5)$ & Mean $(\mathbf{N}=\mathbf{1 0})$ \\
\hline Colour & & 6.0 & $\mathbf{5 . 6}$ \\
& 5.2 & $(0.3)$ & $(0.3)$ \\
Flavour & $(0.2)$ & 7.3 & 6.00 \\
& 6.7 & $(0.1)$ & $(0.2)$ \\
Juiciness & $(0.2)$ & 5.6 & 5.6 \\
& 5.5 & $(0.1)$ & $(\mathbf{0 . 1})$ \\
Overall acceptability & $(0.1)$ & 6.7 & $\mathbf{6 . 4}$ \\
& 6.0 & $(0.2)$ & $\mathbf{( 0 . 2 )}$ \\
\hline
\end{tabular}

Range of Hedonic seale

$\begin{array}{ll}\text { Colour 1 } & =\text { Extremely white }-9=\text { Extremely pink } \\ \text { Flavour 1 } & =\text { Dislike extremely } 9=\text { Like extremely } \\ \text { Tenderness } 1 & =\text { Extremely tough }-9=\text { Extremely tender } \\ \text { Juiciness 1 } & =\text { Extremely dry }-9=\text { Extremely Juicy } \\ \text { Overall acceptability } 1 & =\text { Dislike extremely }-9=\text { Like extremely. } \\ \text { S.E. }=\text { Standard Error (in Parentheses) }\end{array}$


Table 5 CORRELATION BETWEEN LIVEWEIGHT (LW) AND SOME CARCASS PARTS IN JAPANESS QUAIL.

\begin{tabular}{lllllllr}
\hline Parameter & LW & DW & EW & BW & LGW & WW & B + N \\
\hline LW & 1.00 & & & & & & \\
DW & $0.99^{* *}$ & 1.00 & & & & & \\
EW & $0.88^{* *}$ & $0.91^{* *}$ & 1.00 & & & & \\
BW & $0.88^{* *}$ & $0.90^{* *}$ & $0.95^{* *}$ & 1.00 & & & \\
LGW & $0.88^{* *}$ & $0.89^{* *}$ & $0.95^{* *}$ & $0.87^{* *}$ & 1.00 & & \\
WW & $0.37 \mathrm{NS}$ & $0.41 \mathrm{NS}$ & $0.63^{*}$ & $0.43 \mathrm{NS}$ & $0.62^{*}$ & 1.00 & 0.00 \\
B +N & $0.72^{*}$ & $0.73^{*}$ & $0.85^{*}$ & $0.67^{*}$ & $0.86^{*}$ & $0.54 \mathrm{NS}$ & \\
\hline
\end{tabular}

$$
\text { NS - } \mathbf{P}>0.05 \quad * \mathbf{P}<0.05 \quad * * \mathbf{P}<0.01
$$

$\mathrm{LW}=$ Liveweight, $\mathrm{DW}=$ Dressed weight, $\mathrm{EW}=$ Eviscerated weight

$\mathrm{BW}=$ Breast weight, $\mathrm{LGW}=$ Leg weight, $\mathrm{WW}=$ Wing weight

$\mathrm{B}+\mathrm{N}=$ Back + Neck weight. NS $=$ Not significant.

Table 7 EFFECT OF REARING SYSTEM ON CARCASS YIELD (\%) OF JAPANESE QUAIL.

\begin{tabular}{|c|c|c|c|c|}
\hline Parameter & $\mathrm{C}-\mathrm{C}$ & $\begin{array}{l}\text { Management Type } \\
\text { F-C }\end{array}$ & $C-F$ & F - F \\
\hline Live weight $(\mathrm{g})$ & $198.13^{\mathrm{a}}$ & $203.67^{a}$ & $226.75^{a}$ & $239.75^{a}$ \\
\hline Dressed percentage & $91.75^{\mathrm{a}}$ & $96.87^{\mathrm{a}}$ & $95.42^{\mathrm{a}}$ & $96.85^{\mathrm{a}}$ \\
\hline Eviscerated percentage & $78.14^{\mathrm{a}}$ & $83.87^{\mathrm{a}}$ & $83.60^{\mathrm{a}}$ & $85.75^{\mathrm{a}}$ \\
\hline Internal offals & $6.26^{\mathrm{a}}$ & 6.91 & $7.20^{\mathrm{a}}$ & $7.25^{\mathrm{a}}$ \\
\hline Thigh & $11.69^{\mathrm{a}}$ & $13.26^{\mathrm{a}}$ & $13.12^{\mathrm{a}}$ & $13.78^{\mathrm{a}}$ \\
\hline Drumstick & $7.14^{\mathrm{a}}$ & $5.10^{\mathrm{a}}$ & $7.71^{\mathrm{a}}$ & $7.74^{\mathrm{a}}$ \\
\hline Wing & $7.49^{\mathrm{a}}$ & $7.54^{\mathrm{a}}$ & $7.53^{\mathrm{a}}$ & $7.60^{\mathrm{a}}$ \\
\hline Back + Neck & $1984^{\mathrm{a}}$ & $20.60^{\mathrm{a}}$ & $20.01^{\mathrm{a}}$ & $20.71^{\mathrm{a}}$ \\
\hline Breast & $31.28^{\mathrm{a}}$ & $34.82^{\mathrm{a}}$ & $34.35^{\mathrm{a}}$ & $35.67^{a}$ \\
\hline Heart & $0.93^{\mathrm{a}}$ & $0.94^{\mathrm{a}}$ & $0.97^{\mathrm{a}}$ & $1.14^{\mathrm{a}}$ \\
\hline Liver & $1.37^{\mathrm{a}}$ & 1.90 & $1.97^{\mathrm{a}}$ & $1.98^{\mathrm{a}}$ \\
\hline Gizzard & $3.96^{\mathrm{a}}$ & 4.08 & $4.25^{\mathrm{a}}$ & $4.14^{*}$ \\
\hline
\end{tabular}

Means within each row followed by some letter superscript (a) did not differ significantly $(\mathbf{P}>0.05)$. 